\title{
Predation of the bat Pteronotus personatus (Mormoopidae), by a tarantula Lasiodora sp. (Theraphosidae, Araneae), in cave in northeastern Brazil
}

\author{
Sidclay Calaça Dias ${ }^{1}$ \\ Patrício Adriano da Rocha ${ }^{1 *}$ \\ Leoni da Silva Bomfim ${ }^{2}$ \\ Stephen F. Ferrari ${ }^{1}$ \\ Universidade Federal de Sergipe \\ ${ }^{1}$ Conservation Biology Laboratory, Department of Ecology \\ CEP 49100-000, São Cristóvão - SE, Brazil \\ ${ }^{2}$ Departament of Biology \\ * Corresponding author \\ parocha2@yahoo.com.br
}

Submetido em 13/03/2015

Aceito para publicação em 24/09/2015

\section{Resumo}

Predação do morcego Pteronotus personatus (Mormoopidae) pela tarântula Lasiodora sp. (Theraphosidae, Araneae) em caverna no nordeste do Brasil. O crescente número de relatos de morcegos predados por aranhas na última década pode indicar que esses eventos sejam mais frequentes do que aparentam. No presente comunicado notifica-se a predação do morcego Pteronotus personatus (Mormoopidae) pela aranha 'caranguejeira' Lasiodora sp. (Theraphosidae). O evento ocorreu sob o solo da Caverna do Urubu, nordeste do Brasil, e pode ser considerado como uma predação oportunística, como a maioria dos casos de predação de morcegos por estas aranhas. Apesar disso, o registro de outros indivíduos do gênero no local e a alta abundância da espécie de morcego no interior da caverna, pode indicar que essa seja uma interação mais frequente.

Palavras-chave: Chiroptera; História natural; Mygalomorphae; Sergipe

\section{Abstract}

The growing number of reports of spiders preying on bats over the past decade indicates that such events are more frequent than originally thought. The present note reports on the predation of a bat, Pteronotus personatus (Mormoopidae), by a tarantula spider, Lasiodora sp. (Theraphosidae). The event took place on the floor of the Urubu Cave in northeastern Brazil, and may be considered opportunistic, as in the majority of the cases of bat predation by these spiders. However, the high densities of both Pteronotus and Lasiodora in the cave suggest that this type of interaction may be relatively frequent.

Key words: Chiroptera; Mygalomorphae; Natural history; Sergipe 
Spiders are generalist predators that feed primarily on insects (RIECHERT; LOCKLEY, 1984), although some may also prey occasionally on vertebrates (MCCORMICK; POLIS, 1982). Given their size, the theraphosid spiders are effective predators of small vertebrates (MCCORMICK; POLIS, 1982) such as lizards (VIEIRA et al., 2012), frogs (MENIN et al., 2005), and bats (DAS et al., 2012). Nyffeler and Knörnschild (2013) refer to a number of records of spiders feeding on bats in Peru (the spider Avicularia urticans preying on the bat Saccopteryx bilineata), Ecuador (the spider Avicularia sp. preying on Myotis nigricans), Brazil (Lasiodora parahybana preying on an unidentified bat), and India (Poecilotheria rufilata on Pipistrellus ceylonicus). In this note, we present a new record of bat predation by a tarantula of the genus Lasiodora in Brazil.

The event was observed in the Caverna do Urubu ("Urubu Cave"), located in a calcareous rock formation in the municipality of Divina Pastora $\left(10^{\circ} 43^{\prime} 96^{\prime \prime} \mathrm{S}\right.$, $\left.37^{\circ} 09^{\prime} 92^{\prime \prime} \mathrm{W}\right)$ on the right bank of the Sergipe River in the Brazilian state of Sergipe, at around $30 \mathrm{~m}$ asl, and $26 \mathrm{~km}$ from the Atlantic Ocean. The cave is approximately $150 \mathrm{~m}$ long, with internal temperatures of between $24{ }^{\circ} \mathrm{C}$ (near the entrance) and $38{ }^{\circ} \mathrm{C}$ (in its innermost portions), set in a landscape of remnants of Atlantic Forest, mangroves, pastures, and bamboo groves (LEÃO et al., 2003). This formation is a typical "hot cave", a subterranean cavity maintained at a constant high temperature by the combined body heat of high densities of bats (LADLE et al., 2012). The stable microclimatic conditions created by the high bat densities (high humidity and temperatures) may attract a number of other animals (JUBERTHIE, 2000), especially arthropods, which feed on the abundant bat guano, and the decomposing remains of bats and other cave inhabitants (LADLE et al., 2012).

During the collection of data on the bat population of Urubu Cave at about 19h00min on 12th March 2012, one Lasiodora sp. was observed feeding on a bat (Pteronotus personatus) on the cave floor (Figure 1).

FIGURE 1: A theraphosid spider (Lasiodora sp.) feeding on a bat (Pteronotus personatus) on the floor of the Urubu Cave, Brazil.

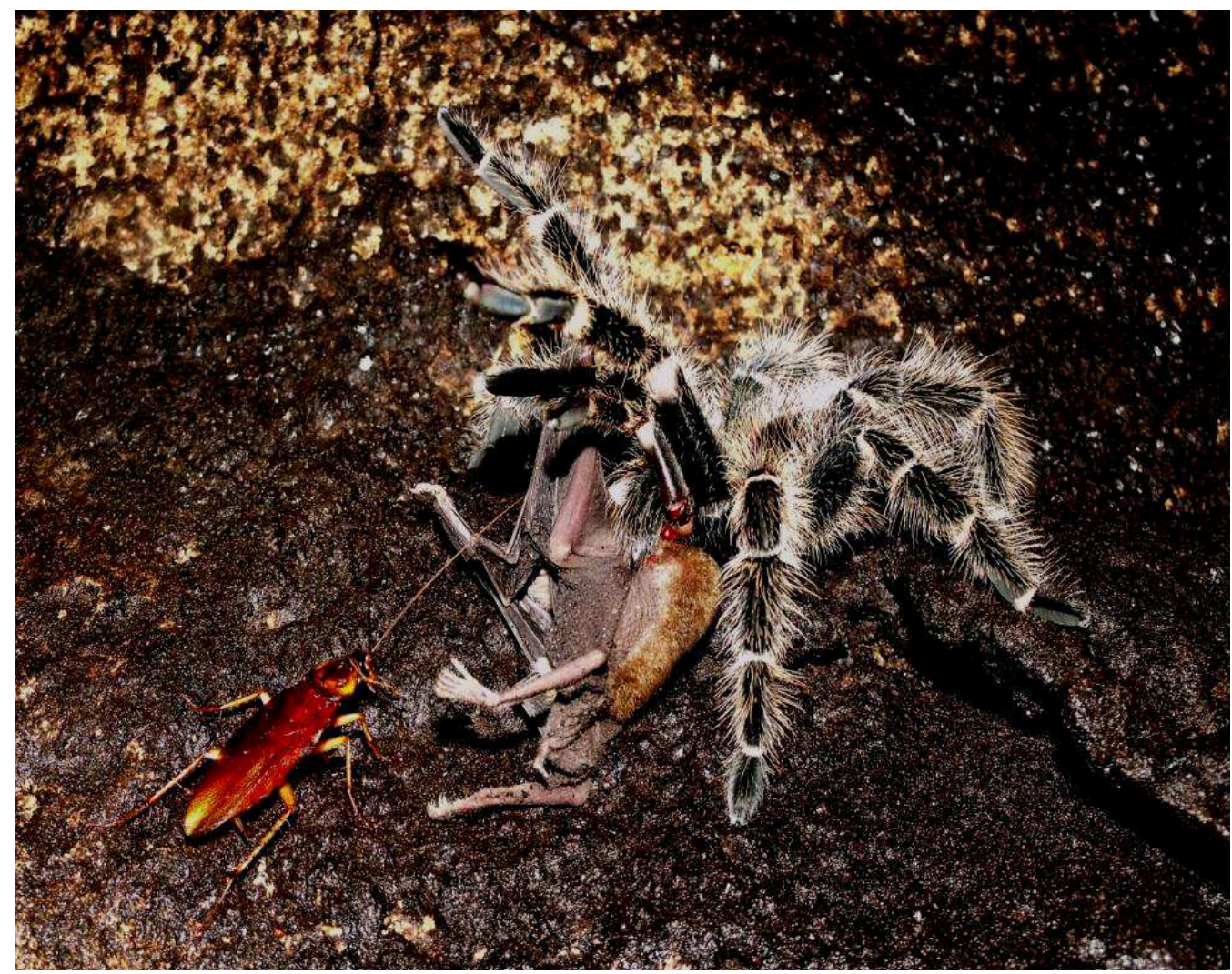


At least seven other theraphosid spiders were observed in the vicinity of the first individual, spaced out at a distance of 2-3 $\mathrm{m}$ from one another. All of these spiders were observed in a "sit and wait" position, with their front legs raised, apparently anticipating the possibility of bats falling to the ground. After the observation, the spider was collected and preserved in 70\% ethanol, and photographs of the chelicerae, tibial spurs and spinnerets was sent to spider specialist Rafael Indicatti (Butantan Institute, São Paulo) for identification. The bats of the genus Pteronotus present in this cave were identified by Rocha et al. (2011).

The predation of bats by spiders does not appear to be uncommon, although records are rare in the literature, with $90 \%$ of the events involved web-building spiders, rather than hunting species (review in NYFFELER; KNÖRNSCHILD, 2013). As terrestrial ambushers, Lasiodora would not normally prey on bats, and only one case of a Lasiodora parahybana eating a bat has been reported (NYFFELER; KNÖRNSCHILD, 2013). The event recorded in the present study almost certainly reflects the extraordinary circumstances typical of the hot caves.

Given the high density of bats in this cave, collisions between individuals, or between bats and the cave walls, are relatively frequent during certain periods, such as the mass exodus occurring at the beginning of each night (Patrício Adriano da Rocha, personal observation). The behavior of the spiders indicated that their presence in the cave may have been related to this phenomenon, as suggested by Gouveia et al. (2009), who observed toads preying on bats at the entrance of another hot cave in Sergipe. In the Urubu cave, the predation of bats by the spiders may be further facilitated by the seasonal recruitment events that occur in March (the period of the present study), when many of the older individuals in the colony die off and fall to the cave floor, where they become easy prey for spiders and other predators (P.A.R., personal observation).

\section{Acknowledgements}

Rafael P. Indicatti (Butantan Institute, São Paulo) helped us to identify the spider. Stephen Francis
Ferrari (processes 302747/2008-7 and 483220/2013) and Patrício Adriano da Rocha (501701/2013-3 and 150407/2015-7) thank CNPq for research stipends.

\section{Reference}

DAS, K. S. A.; SREEKAL, L. K.; ABDURAHIMAN, O. Predation on the Kelaart's Pipistrelle bat, Pipistrellus ceylonicus Kelaart (Chiroptera:Vespertilionidae), by the reddish parachute tarantula, Poecilotheria rufilata Pocock (Araneae: Theraphosidae), in Chinnar wildlife sanctuary, Kerala, India. Tropical Natural History, Bangkok, v. 12, n. 2, p. 257-260, 2012.

GOUVEIA, S. F.; ROCHA, P. A.; MILKALAUSKAS, J. S.; SILVEIRA, V. V. Rhinella jimi (Cururu toad) and Leptodactylus vastus (Northeastern pepper frog). Predation on bats. Herpetological Review, St. Louis, v. 40, p. 210, 2009.

JUBERTHIE, C. The diversity of karstic and pseudokarstic hypogean habitats in the world. In: WILKINS, H.; CULVER, D. C.; HUMPHREYS, W. F. (Ed.). Ecosystems of the world subterranean biota. Amsterdam: Elsevier, 2000. p. 17-29.

LADLE, R. J.; FIRMINO, J. V. L.; MALHADO, A. C. M.; RODRÍGUEZ-DURÁN, A. Unexplored diversity and conservation potential of neotropical hot caves. Conservation Biology, San Francisco, v. 26, n. 6, p. 978-982, 2012.

LEÃO, T. C. C.; LOBO, D. ; SILVA, E. J. Conservação, geologia e levantamento da fauna de invertebrados associados ao guano da caverna do Urubu (SE-10), Riachuelo, Sergipe. In: CONGRESSO BRASILEIRO DE ESPELEOLOGIA, 27, 2003, Januária. Anais..., Janúária: Sociedade Brasileira de Espeleologia, 2003. p. 135-139.

MCCORMICK, S.; POLIS, G. A. Arthropods that prey on vertebrates. Biological Reviews, Cambridge, v. 57, p. 29-58, 1982. MENIN, M.; RODRIGUES, D. J.; AZEVEDO, C. S. Predation on amphibians by spiders (Arachnida, Araneae) in the Neotropical region. Phyllomedusa, Belo Horizonte, v. 4, n. 1, p. 39-47, 2005.

NYFFELER, M.; KNÖRNSCHILD, M. Bat predation by spiders. Plos One, Cambridge, v. 8, n. 3, e58120, 2013.

RIECHERT, S. E.; LOCKLEY, T. Spiders as biological control agents. Annual Review of Entomology, Palo Alto, v. 29, p. 299 320, 1984.

ROCHA P. A.; FEIJÓ, J. A.; MIKALAUSKAS, J. S.; FERRARI, S. F. First records of mormoopid bats (Chiroptera, Mormoopidae) from the Brazilian Atlantic Forest. Mammalia, Paris, v. 75, n. 3, p. 295-299, 2011.

VIEIRA, W. L. S.; GONÇALVES, M. B. R.; NÓBREGA, R. P. Predação sobre Tropidurus hispidus (Squamata: Tropiduridae) por Lasiodora klugi (Araneae: Theraphosidae) na região de caatinga semiárida do nordeste do Brasil. Biota Neotropica, Campinas, v. 12, n. 4, p. 263-265, 2012. 